\title{
The problem of the autocatalytic origin of culture in Juri Lotman's cultural philosophy
}

\author{
Linnar Priimägi \\ Dept. of Advertising and Media, Tallinn University \\ 27 Narva St., 10120 Tallinn, Estonia \\ e-mail: tristan@tlu.ee
}

\begin{abstract}
The origin of culture remains in the sphere of hypotheses. Although the hypotheses derive from two presumptions: first, how the structure of culture is envisaged, and secondly, how culture is thought to function. Juri Lotman dealt with both aspects of culture, initially the structural and typological and later the dynamic aspects. Thereby, he arrived at the culturalphilosophical hypothesis of the autocatalytic origin of culture. A catalyst is a component of a chemical reaction which itself doesn't transform during the reaction, but whose presence is needed to guarantee the reaction (or to stimulate it). Thus, autocatalysis is a paradoxical situation in which the genesis of something presumes the pre-existence of the final product. The paradox of the autocatalysis of culture lies in the fact that culture cannot emerge from anything other than from culture itself, from its own germination. In 1988, speaking about the autocatalysis of culture, Lotman refered to the cultural historicist Nikolai I. Konrad (1891-1970), who undoubtedly borrowed this idea from Jacob Christopher Burckhardt (1818-1897). This undiscovered connection reminds us of the fact, that a model for autocatalysis (or an autopoiesis) was basic to Naturphilosophie of the 19th century. In the 20th century, this was represented by Vladimir I. Vernadsky (1863-1945), from whom Lotman in 1982 received the impetus to formulate the concept of semiosphere as well as of the autocatalysis of culture. The autocatalysis model of culture is culturally diachronical, the semiosphere is, however, a synchronical one. In both cases, the natural philosophical cytology of the 19th century was Lotman's semiotical meta-language.
\end{abstract}




\section{Models of cultural memory: The world of names}

The cultural history reflected in consciousness can be modeled as a system of proper names, the nodes of which are the cultural phenomena, which are indicated by proper names (more often personal names). The greatest portion of cultural memory is encoded in proper names, and participation in some culture primarily means the ability to orient among the culture's proper names. Being cultured is the ability to speak using names. ${ }^{1}$ Georg Wilhelm Friedrich Hegel has aptly commented on the personal nature of cultural history: "There are two kinds of sequences (Folgerungen): some are just the working out of principles into further details; some, however, are the return to deeper principles; historicality consists of just this, to indicate which individuals possess such a subsequent deepening of thought and its unlocking" (Hegel 1830: xvii-xviii).

To the mythological consciousness it is self-evident, that looking back to the dawn of time, to the beginning of everything, there is One Very First Name. Together with names marking cultural phenomena all culture is collected into this primeval beginning. This One Very First Name belongs to the Creator of Culture, to the Demiurge, or the primeval being, "from whom all has gotten its beginning", "from whom everything has started to be" - Bochica of the Indians of Colombia, the Polynesian Maui, the Egyptians' Osiris and Toth, the Greek Prometheus.

Such a narrowing of the proper name network into the Very First Name, as a clearly mythological thought process cannot be acceptable to the scientific, purely logical understanding of the development of culture. The scientific cultural history operates on a concept of the dispersal of proper names, according to which looking back, personal

1 Here we cannot leave unmentioned a pertinent episode in "The Winners" (Los premios, 1960) by the Argentinian author Julio Cortázar, which describes the shipboard meeting of two intellectuals starting out on a trip around the world: "Did you already find the bar? It is upstairs next to the dining room. Unfortunately I also saw a piano in the corner, but we have the chance to cut the strings in the next day or two." - "Or to cause it to be so out of tune that everything played on it sounds like Křenek," answers the other. Later recalling the event, the first remarks: see, the trip didn't start off badly — "someone in the ship's corridor mentioned Křenek's name — just like that, in passing!” (Cortázar 1979: 72-73). 
names thin out and finally disappear, giving ground to the anonymity of cultural carriers.

Positive facts, of course, confirm such an understanding. In the depth of time, people were quite dispersed. For instance, today we know of only 200-300 Neanderthals, i.e. about one individual per every thousand years! Here names cannot even be spoken of. Therefore, in scientific descriptions of the genesis of culture, we have to operate without names, and accept that the "four energy principles which our modern technology uses have come from unknown and unnamed ice age inventors, who lived on earth thousands of years before us" (Lips 1968: 93).

Yet, such anonymity makes thinking about culture uncomfortable, which is why hidden mythological tendencies can be found in even the most seriously scientific treatment.

Hidden mythological thinking doesn't operate directly with the names of gods or heroes, but substitutes vague pre-historic people with a Man, as such, who starts to act as a mythological being: "From the beginning, man has tried by using different resources to lighten his work burden" (Lips 1968: 80). This Man, who is again mythologized, will successfully compete with Prometheus: "How man first came in contact with fire which he wished to tame and preserve, this remains undiscovered," says scientologist John D. Bernal (1962: 43) figuratively.

Such examples confirm, that the question is not just in stylistic clumsiness, but actually in a mythological thought process for the treatment of culturology which claims to be purely scientific: an anonymous collective is treated as an individual who has secretly been granted a researcher's absolute consciousness.

\section{Nature and culture: Dualism or monism?}

To conceive of Culture only as something different than Nature does not explain its genesis.

The hypothesis that the transition from Nature to Culture occurs with the help of some outside third force is made inevitable by the dualistic opposition of nature and culture.

This is not just a typical mythological, but also a religious and theological understanding of Culture's (and civilization's) relationship 
with Nature. Referring to Thomas Aquinas, who clearly emphasizes that intellect and the spiritual culture built on it cannot be a function or side function of some material, bodily (natural) organ but has a separate origin. ${ }^{2}$ The endurance of this conviction is confirmed by Pope Pius XII in his encyclical on the topic of evolution Humani generis (1950), which allows for the possibility of researching physical evolution, but emphasizes the divine origin of the soul and (spiritual) culture.

And finally, such a Nature and Culture dualism also characterizes such pseudo-religious conceptions of culture as Erich von Däniken's hypothesis on the extraterrestrial origin of civilization: those from outer space cultivate the earthlings until they become reasoning beings. In such a way, E. von Däniken surmises that a new race can emerge, which can jump over a certain portion of natural evolution (Däniken 1972: 95).

Notably more interesting, and problematic are efforts to explain the genesis of Culture monistically, efforts to build a bridge between Nature and Culture. These have existed for a long time and, at least at first glance, they can be divided into materialistic and idealistic. As the first example, we should mention Democritus's understanding that human culture has developed as a direct imitation of animal activity: weaving-sewing taught by spiders, house building by swallows, singing by swans and nightingales. Therefore, culture has a natural, animalistic origin.

Such primitivism and naturalism is contrasted with the common idealistic, pantheistic concepts of natural and divine beginnings, which - in case they are connected with the development idea - see the premise for the rise of Nature into Culture in the spirituality of nature itself. This is the legacy of natural philosophy.

The leading figure of modern natural philosophy became Friedrich Wilhelm Joseph Schelling with the works "Ideas for a Philosophy of Nature" (Ideen zu einer Philosophie der Natur, 1797), "On the World Soul" (Von der Weltseele, 1798) and "First Plan of a System of the Philosophy of Nature" (Erster Entwurf eines Systems der Naturphilo-

\footnotetext{
2 S. th., P. I, qu. 7, art. 2 ad 3: "Hoc ipsum quod virtus intellectus extendit se quodammodo ad infinita, procedit ex hoc quod intellectus est forma non in materia, sed vel totaliter separata, sicut sunt substantiae Angelorum, vel ad minus potentia intellectiva, quae non est actus alicuius organi in anima intellectiva copori coniuncta" (Thomas Aquinas, Summa theologica, 1274).
} 
sophie, 1799). Having studied mathematics, physics and medicine for two years at Leipzig University, he knew the contemporary sciences quite well, as Alexander von Humboldt, the great German naturalist, admits. F. W. J. Schelling's main natural philosophical position was pantheistic hylozoism - life exists in all things as the finalistic principle of polarity and reproduces itself (as natura naturans).

\section{Theory of the autocatalysis of life}

The cellular theory was founded 1838 by the German scientists, botanist Matthias Jacob Schleiden and anatomist-physiologist Theodor Schwann. They asserted that cells are the basic unit of all living organisms and that without cells there is no life. (The arguments on the topics of the life of viruses were a long way off.) In the period 1860/70, the German physician Hermann Eberhard Friedrich Richter presented the slogan Omne vivum ab aeternitate e cellula - "From the beginning of time, everything living comes from cells". The leading Prussian scientist Rudolf Virchow affirmed in his work "Cellular Pathology" (Die Cellularpathologie, 1858), that cells can only arise from cells (Omnis cellula e cellula).

During the 19th century, cell theory was still largely the arena of supposition. Recall Ernst Haeckel's "theory of cell souls"! Behind the views of R. Vichow, we can also recognize F. W. J. Schelling's natural philosophy.

Actually the question of life's biogenesis or a-biogenesis is also natural philosophical. (An example from the 19th century is Jean-Baptiste Lamarck's theory of the parallel genesis of soil as a compound of elements and plants as life form.) For instance, biogenesis is promoted today by Srîla Prabhupāda, the great teacher of Krishna with the very emotional argument: "We must teach that life is born from life, not from material. We must make this fact known, because we possess the truth, while scientists rely on fallacies" (Prabhupāda 1999: 44).

With references to Indian religion, Vladimir I. Vernadsky confirms in the speech "Origin and Eternity of Life" (Nachalo $i$ vechnost' zhizni, 1921) that the origin of live matter only come from live matter. In addition to these religion-themed arguments, V. I. Vernadsky also refers to natural philosophy, most emphatically to the cytologist H. E. F. Richter. With positivistic arguments, V. I. Vernadsky actually de- 
fends the postulates of natural philosophy claiming that, since the physical conditions on Earth were not conducive to life, "life could have arrived on Earth from outside", as conserved particles from outer space, or that "life is a cosmic, not a specifically earthly occurrence". In summary, he writes "Life is eternal in so far as the Cosmos is eternal, and it has always been carried forward by biogenesis" (Vernadskij 1989: 102, 104, 105).

In his arguments, V. I. Vernadsky relys on Francesco Redi's, the 17 th century Italian naturalist's, position omne vivum ex vivo — "all life is born from the living" and recalls once more H. E. F. Richter's cell theory, saying that "Redi's principle can be applied to cells, as the smallest organized elements" (Vernadskij 1989: 113).

According to the knowledge of today, H. E. F. Richter's theory does not, however, apply on the level of organelles. Many parts of cells, for instance mitochondria, as well as plastides in plant cells, in which an organism's chemical energy source adenosine triphosphate (ATP) is produced and which contain DNA, are actually created by splitting from identical cell particles. All other cell particles, however, do not emanate from division but are produced internally from material synthesized in the cell. ${ }^{3}$

V. I. Vernadsky's assertion that "the evolution process is nothing more than different expressions of one and the same substrate - the unitary life" is actually the core of F. W. J. Schelling's Naturphilosophie.

\section{The autocatalysis of culture}

Significantly, semiotician Juri Lotman found an application for this model of natural philosophical biogenesis of life in the spiritual sphere. On March 19, 1982, he wrote to his colleague Boris A. Uspensky:

I am reading Vernadsky with great pleasure and find many of my thoughts there (I am writing articles on semiotics). Reading Vernadsky, I am struck by one of his statements. You know, that once at our Moscow seminar [...], I dared to express the belief that a text can exist (that is, be socially acknowledged as text) when it is preceded by another text, and that every developed

3 The author thanks Andres Piirsoo of the Tartu University for useful comments. 
culture must have been preceded by developed culture. And now I discover in Vernadsky the deeply reasoned thought, based on long cosmic geological research, that life can only originate from the living, that is, only when it is preceded by life. Therefore, he defines living and dead (he says: inert) material as two primeval elements, which are expressed in different forms, but remain forever separated from and in contact with each other. I am convinced, however, that thought as well cannot develop evolutionally from non-thought (a separate issue is that apparently we should not deny thought in the case of animals and maybe life without thought is impossible at all). For just as life consists of all forms of life activity from the work of anaerobic bacteria to the most complicated forms, so too thought (semiosis) takes both simple and complicated forms.

It is interesting, that Vernadsky constructs his arguments as an empiricist and positivist, taking care to distance himself from theological and mystical thought. He argues thusly: science only can be based on observable or constructed facts. The moment of changing non-life into life is not traceable or constructable anywhere in the universe. Even going back a million years, we still find some forms of organic life (or traces of its existence) and nonlife. And all hypothesis of the [non-living] origin of life are speculation, which are based on a hypothesis, that one [i.e. life matter] must develop from the other [i.e. non-life matter]. I believe for my part that neither the acceptance of the existence of primeval rationality needs a theological or opposing [i.e. atheistic] view. This only indicates a simple fact: we cannot decide, whether light impulses from stars are semiotic signals or not, because we lack the presumption of rationality. Only the previous existence of the semiotic sphere makes a message into message. Only the existence of intelligence explains the existence of intelligence. (Lotman 2001: 683-684; my emphasis - L. P.)

Six years later, Lotman presented a paper "University and science" (Universitet $i$ nauka, 1988) in Bologna. He refers to the correspondence of Nikolai I. Konrad, the Russian orientalist, with Arnold J. Toynbee, the English cultural historian (which was published in Russian in 1967):

N. I. Konrad wrote to A. Toynbee and argued against his ideas on the ruin of culture, that "The Iliad certainly does not mark the beginning of a new literature; it is a summary of all previous culture, but a summary, which has been made by a new people, who have inherited this culture. The real beginning of Greek literature is the primitive poetry and prose, which we find in the "post-Homeric period". (Lotman 1989: 51).

It should be said, that here N. I. Konrad is actually repeating a thought expressed by Jacob Christopher Burckhardt, the Swiss cultural 
researcher in his work "History of Greek Culture" (Griechische Kulturgeschichte, 1898/1902):

Homer could not, at any rate, have been the first artistic poet; nevertheless his tone and style are possible only as the result of a long tradition of rhapsodists and schools of rhapsodists; this is the only way to explain the unerring assurance of the treatment. Most probably the tone and the style of such narrations were both created by very talented individuals during ancient times. (Burckhardt 1898/1902: 156-157)

Ample references to J. C. Burckhardt allow us to conclude with confidence, that the Swiss author's works were familiar to N. I. Konrad and significantly influenced his views.

Although N. I. Konrad creates a model situation from J. C. Burckhardt's single observation, claiming analogous phenomena in Indian culture:

It seems to me that in the same way we can approach another enigmatic literary relic, the Indian Rammayana. [...] Perhaps there is a similar historical mystery here as in the case of The Iliad. In any case, the Rāmãyana is not primitive. Is no starting point" (Konrad 1974: 278).

And he generalizes that "lost cultures are reborn not only transformed, but also as one with an enormous mass of matter which has been already created by its own [i. e. Rāmāyana's] contemporary time" (Konrad 1974: 278).

By connecting these thoughts by N. I. Konrad with V. I. Vernadsky's natural philosophical views, Lotman puts into words the basic thesis of cultural autocatalysis: "We can assume, that the origin of a developed civilization needs the existence of another developed civilization, even if the other one has already been destroyed" (Lotman 1989: 51; my emphasis - L. P.).

\section{From typology to dynamics}

Two phases can be detected in the development of Juri Lotman's cultural semiotical views - typological and dynamic (Torop 1999: 387-404). 
In the phase dealing with typology, in "Articles on Typology of Culture" (Stat'i po tipologii kul'tury), the collection published in 1970, Lotman admits that "cultures are communciative systems, and human cultures are created on the basis of this all-encompassing semiotical system, which is natural language" (Lotman 1970: 13). This expresses Ferdinand de Saussure's understanding, that natural language is the primary modeling system, and different cultural notations are but secondary modeling systems which have developed from this example: "Language is a system for expressing concepts and therefore it can be compared to the scripture, sign language of deafmutes, symbolic rituals, forms of politeness, military signals, etc. etc. It is just the most important of these systems" (Saussure 1977: 54).

But at the same time, Lotman drops a remark, which will later develop into his basic thesis of cultural semiotics: "A society, which is built on non-sign (for instance para-psychological) communications, would have a totally different choice of opportunities for building a culture" (Lotman 1970: 13).

From here Lotman's linguistic-pictorial dualism starts to develop from F. de Saussure's linguistic monism. Lotman admits here, that the primacy of natural language in today's human communication is not the only possibility, rather at some point mankind stood - in a figurative sense - before a choice, whether to go the route of verbal or pictorial communication. At some time at the beginning of human culture, the choice was made in favor of verbal language.

The banishment of the picture by the word as an information carrier, the competition of the two in cultural history is repeatedly treated by Lotman, especially in his last book "Culture and explosion" (Kul'tura $i$ vzryv, 1992) using dreams as an example of the purely pictorial medium, saying that

the speech sphere with its opportunities brought into play more powerful mechanisms and destroyed the potential possibilities of dreams to become a developed realm of a self-abundant consciousness. [...] The development of speech forced this cultural realm into the background and promoted its further simplification. (Lotman 1992a: 220-221)

The cornerstone of Lotman's cultural dynamic model is the assertion that pictorial communications have not disappeared, but have preserved its primary role as the creator of basic heterogeneity in the culture and thereby as the motor of cultural dynamics. 
The dynamics of culture as a complete semiotic system is not derived from the fact that the existing languages of cultural texts are simply different and translatable from one to the other, but from the fact, that they are different in principle, founded on two equal primary modeling systems. In 1973, Lotman asserts in his article "Some remarks on the structure of a narrative text" (Zamechaniya o strukture povestvovatel'nogo teksta) that following in F. de Saussure's footsteps and accepting natural language as the only primal language of human communication is "mere habit":

In discrete verbal messages, the text consists of signs, in the other case [i.e. in the case of pictorial texts] there are not signs, and the message is delivered by the text as a whole. And if we add discretion, separating the sign-like structural elements, then we must treat this as the mere habit of seeing verbal intercourse as the primary if not only form of communicative contact and to equate pictorial texts with verbal ones. (Lotman 1973: 383-384)

Also in the speech, in which Lotman formulated the idea of cultural autocatalysis, he speaks about "the basic bilinguilism (of conventional and iconic languages) of a culture", where

the existence of two such mutually untranslatable languages, conventional (discrete, verbal) and iconic (continuous, spatial), is the necessary assumption for a new information generating (that is "thinking") device (ustrojstvo). The tension between discrete and continuous mechanisms has been detected in every artistic text and in the culture as a whole (Lotman 1989: 50-51).

\section{The beginnings of culture}

Juri Lotman's answer to the question about the provenience of culture's basic dualism is not derived from cultural theory, but from cultural philosophy and is patterned on 19th century natural philosophy.

We are dealing with a hypothesis. But there is not this only one.

In the article "On dynamics of culture" ( $O$ dinamike kul'tury, 1992), Lotman raised other hypotheses about the "very first beginning" of culture, surmising that "human culture got its beginning from a large-scale, maybe catastrophic, giant explosion". As a result, a pre-ritualistic and pre-artistic language of gestures was created, "a consentaneous system of movements, calls and melodic cries, which, 
when semiosis became more complicated, changed from an "action speech" into a "speech of conventional marks". With the assertion, that from that moment "mankind's future history changed into a history of using words", where "semiotics (the function and role of speech) [becomes] the dominant mechanism of history" (Lotman 1992b: 9-15), Lotman returns to his drafted hypothesis of 1970 that human culture could probably have developed into a pictorial medium dominant one.

Lotman had no opportunity to integrate his views on the origin and dynamics of culture; therefore their coherence still awaits explanation. It must certainly be noted, that Lotman, as a person with an extremely wide horizon, used different models to explain his concepts, which reflected the development and enrichment of his theoretical positions.

Thinking of semiosphere units, he sometimes obviously thinks of monads (as defined by Gottfried Wilhelm Leibniz), writing:

In the same way that an individual is a part as well as a holistic analogue of a collective, the isolated history of literature, or of some other art discipline, or of art as a whole, can be treated as well as a part of cultural mix or as an analogue of the whole. (Lotman 1992b: 18)

Let us compare this thought to paragraph 67 of G. W. Leibniz's "Monadology" (La Monadologie, 1714): "Every portion of matter may be conceived as a garden full of plants and a pond full of fish. But every branch of a plant, every limb of an animal, and every drop of the fluids within it, is also such a garden or such a pond."4

On the other hand, in Lotman's mind's eye he sees the semiosphere as an organism, which is devided into cells: "for the mentioned semiosphere [i.e. a subset unit of semiosphere] reality changes into "reality for itself" only to the extent that it is translatable into its language (just as cell can assimilate external chemical matter only when these have turned into appropriate biochemical structures - both cases are the examples of the same rule)" (Lotman 1992c: 14). Lotman compares the border of a semiosphere unit to the membrane of a living cell. For this reason, he always sees the border as a border of individuality - as opposed to Mikhail M. Bakhtin who treats borders "non-cellularly" (Bakhtin 1979: 405).

$4 \quad$ E.g., http://stripe.colorado.edu/ morristo/monadology.html. 
The model of cultural autocatalysis is a temporal, even historical (diacronical) model, the semiosphere, however, is a cultural spatial (synchronical, although dynamic) model. However, in both cases, Lotman's semiotic meta-language is the 19th century natural philosophical cytology.

\section{References}

Bakhtin, Mikhail M. 1979. Estetika slovesnogo tvorchestva. Moskva: Iskusstvo.

Bernal, John D. 1962 [1954]. Teadus ühiskonna ajaloos. [Science in History.] Tallinn: Eesti Riiklik Kirjastus.

Burckhardt, Jacob 1898/1902. Griechische Kulturgeschichte, II. Leipzig: Kröner.

Cortázar, Julio 1979. Die Gewinner. Roman. Leipzig: Philipp Reclam jun.

Däniken, Erich von 1972. Aussaat und Kosmos. Spuren und Pläne außeridischer Intelligenzen. Düsseldorf: Econ Verlag.

Hegel, Georg Wilhelm Friedrich 1830. Encyclopädie der philosophischen Wissenschaften im Grundrisse. Zum Gebrauch seiner Vorlesungen. Heidelberg: Verwaltung des Oßwald'schen Verlags / C. F. Winter.

Konrad, Nikolai I. 1974. Izbrannye trudy. Istorija. Moskva: Nauka.

Lips, Julius E. 1968 [1956]. Asjade algusest. Inimese kultuuriajalugu. [The Origin of Things.] Tallinn: Valgus.

Lotman, Juri M. 1970. Stat'i po tipologii kul'tury, I. Tartu: Tartu Riiklik Ülikool.

- 1973. Zamechanija o strukture povestvovatel'nogo teksta. Trudy po znakovym sistemam (Sign Systems Studies) 6: 382-386.

- 1989. Universitet i nauka. Ülikool (Acta Publica Universitatis Tartuensis) 1: 49-53.

- 1992a. Kul'tura i vzryv. Moskva: Gnosis.

- 1992b. O dinamike kul'tury. Trudy po znakovym sistemam (Sign Systems Studies) 25: 5-22.

- 1992c. Izbrannye stat'i v treh tomah, I. Tallinn: Aleksandra.

- 2001. Semiosfera. Sankt-Peterburg: Iskusstvo-SPB.

Prabhupāda, Śr̄̄ Śrīmad A. C. Bhaktivedanta Swami 1999 [1990]. Elu sünnib elust. Hommikused jalutuskäigud Śrī Śrimad A. C. Bhaktivedanta Swami Prabhupādaga. [Life Comes From Life.] Tallinn: The Bhaktivedanta Book Trust.

Saussure, Ferdinand de 1977. Trudy po jazykoznaniju. Moskva: Progress.

Torop, Peeter 1999. Semiootika piiril. In: Lotman, Juri, Semiosfäärist. Tallinn: Vagabund, 387-404.

Vernadskij, Vladimir I. 1989. Nachalo i vechnost' zhizni. Moskva: Sovetskaja Rossija. 


\section{Проблема автокаталитичности культуры в философии культуры Юрия Лотмана}

Проблема возникновения культуры остается в области гипотез. Но эти гипотезы опираются на две предпосылки: во-первых, каким представляют строение культуры и, во-вторых, каким представляется функционирование культуры.

Юрий Михайлович Лотман рассматривал оба аспекта культуры: сначала структурально-типологический, позже динамический. Отсюда возникла гипотеза об автокаталитическом возникновении культуры.

Катализатором называется компонент химической реакции, который сам в ходе реакции не изменяется, но который обеспечивает или возбуждает реакцию. Автокатализ представляет собой парадоксальную ситуацию, где для возникновения чего-то нужно наличие этогоже “чего-то". Автокаталитичность культуры заключается в парадоксе: культура не может возникнуть без наличия культуры.

В 1988 году Ю. М. Лотман указывает по поводу автокаталитичности культуры на историка культуры XX века Николая Иосифовича Конрада (1981-1970), который несомненно вычитал эту идею у историка культуры XIX века Якоба Кристофера Буркгардта (18181897). Эта не раскрытая до сих пор связь указывает на факт, что автокаталитическая (или “автопойэтическая”) модель служила основой натурфилософии XIX века. В XX веке эту философию представлял В. И. Вернадский (1863-1945), идеи которого послужили в 1982 году Ю. М. Лотману при формулировании концептов как семиосферы так и автокатализа культуры.

Автокаталитическая модель культуры является диахронической, семиосфера - синхронической моделью культуры. Но в обоих случаях семиотическим метаязыком Ю. М. Лотмана была натурфилософская цитология XIX века.

\section{Kultuuri autokatalüütilise päritolu problem Juri Lotmani kultuurifilosoofias ja ka sisukorras parandada}

Kultuuri teke jääb hüpoteeside alaks. Kuid need hüpoteesid tulenevad ikka kahest eeldusest: esiteks, millisena kujutletakse kultuuri ehitust, ja teiseks, kuidas arvatakse kultuuri funktsioneerivat.

Juri Lotman käsitles mõlemat kultuuri aspekti — algul strukturaaltüpoloogilist, hiljem dünaamilist. Seeläbi jõudis ta ka kultuurifilosoofilise hüpoteesini kultuuri autokatalüütilisest tekkest. 
Katalüsaatoriks nimetatakse keemilise reaktsiooni komponenti, mis ise reaktsioonis ei muutu, kuid mille olemasolu alles tagabki reaktsiooni toimumise (või ergutab seda). Autokatalüüs kujutab endast niisiis paradoksaalset olukorda, kus millegi tekkeks on vajalik sellesama asja eelnev olemasolu. Kultuuri autokatalüütilisus seisneb paradoksis, et kultuur ei saa tekkida millegi muu kui kultuuri olemasolu eeldusel, omaenda "juuretisest".

1988. aastal viitab J. Lotman kultuuri autokatalüüsist rääkides XX sajandi kultuuriloolasele Nikolai Konradile (1891-1970), kes selle idee kahtlemata sai XIX sajandi kultuuriloolaselt Jacob Christopher Burckhardtilt (1818-1897). Too avamata seos juhib tähelepanu tõsiasjale, et autokatalüüsi (või autopoiesis'e) mudel oli üldse aluslik XIX sajandi natuurfilosoofias. XX sajandil esindas seda Vladimir Vernadski (18631945), kellelt J. Lotman 1982. aastal sai tõuke niihästi semiosfääri kui ka kultuuri autokatalüüsi kontseptsiooni formuleerimiseks.

Kultuuri autokatalüüsi mudel on kultuuri diakrooniline, semiofäär aga sünkrooniline mudel. Kuid mõlema puhul oli J. Lotmani semiootiliseks metakeeleks XIX sajandi natuurfilosoofiline tsütoloogia. 